would be discovered, and a safe return would be ensured; for the advanced parties would be able to fall back upon their consort, whence, in case of accident, the whole expedition could retreat to the Danish settlements in Greenland.

The direct advantages offered by this route are, the discovery of the northern side of Greenland, and the prospects of securing the most valuable results in the various branches of scientific research, -in geography, hydrography, botany, zoology, ethnology, geology, geodesy, and meteorology : but all the advantages to science cannot possibly be foreseen. Among the possible results enumerated by the Geographical Society are these:Completing the circle of Greenland, ascertaining the extent and nature of its northern point, and discovering the conditions of land and sea in that area; supplementing the investigations of the Challenger expedition as to the bottom of the ocean; the probability of forest vegetation, proved to have flourished on what is now the Greenland coast, having extended over the Pole itself, thus confounding all previous geological reasoning as to the climate and conditions of the globe during the Tertiary period; a more complete knowledge of the teeming life of the Arctic Ocean ; a knowledge of the customs and mode of life of the supposed dwellers in the unknown area, of whose former existence there is proof, who have no communication with the most northern known people, and who have probably been isolated for centuries; a knowledge of the kinds of microscopic vegetation inhabiting the northern Greenland seas, which would throw great light on investigation into the age of the rocks of our own island, and on the later changes of the climate of the northern hemispkere, besides the geological results, in rocks and fossils, and the observations on glacial action, which would be yielded by the examination of a long coast line; observations of the pendulum and of the dip and intensity of the needle ; and observations as to temperature, pressure, winds, and currents. These manifold advantages, of the highest importance-in spite of the vague Philistine tirade of the Times-are confirmed and supplemented by the documents of the other societies.

As to the element of danger, it is clearly shown in the Linnean Society's paper that, as compared with explorations in Africa, Australia, and elsewhere, Polar voyages, North and South, show a comparative immunity from loss and hardship; and during the last few years experience has been so fruitful in her teachings, that the element of discomfort and danger may now be reduced to a minimum. The Geographical Society concludes its documents by adding to the other advantages that another generation of naval officers will be trained in ice navigation,--and they will be needed in 1882 ,-that opportunities will be offered for distinction, and that a great benefit will be conferred on the Navy, and through the Navy on the country. The belief is expressed that all classes of the people will unite with men of science in the desire that the tradition of Arctic discovery should be preserved and handed down to posterity, and that Englishmen should not abandon that carcer of noble adventure which has done so much to form the national character, and to give our country the rank she still maintains.

All this is irresistible.

\section{FORESTRY IN ITS ECONOMICAL BEARINGS}

TO what extent the climate of any portion of the surface of the earth can be changed by human labour is still an open question. Certain districts of the globe we are accustomed to look upon as condemned by Nature to perpetual sterility. The arid deserts of Africa and Central Asia, the frozen realms of Siberia, appear as if predestined to a gloomy lifeless solitude. To reclaim them to human control and human habitation may be one of the problems of the future. That climates have changed materially within recent times, we know as a historic fact. Macaulay has made us familiar with the damp fogs and perpetual rain-clonds with which our island was invested during the period preceding the arrival of the Danes and the Saxons. Much of the amelioration of climate which has since taken place is doubtless due to the increased cultivation of the land, and the extent to which the fendistricts have been drained ; but the main agent has probably been the destruction of the forests which then clothed a large portion of the island.

The mode in which forests act in increasing the amount of moisture in the atmosphere is much misunderstood. Even in an article which recentiy appeared in the pages of so well-informed a journal as the Pall Mall Gazette, it is affirmed that this effect is due to the attraction exercised by the trees on the rain-clouds. The principle by which trees act in effecting this is, however, at least mainly, by acting as pumps in drawing up the superfluous moisture from the soil. The most trustworthy experiments show that, under normal circumstances, plants have no power of absorbing through their leaves water, either in the fluid or gaseous state; their supplies are obtained entirely through their roots; and the superfluous moisture is evaporated from the leaves. The amount of aqueous vapour thus delivered into the atmosphere by vegetation is enormous, and has been the subject of careful investigations by French and German botanists. Von Pettenkofer recently detailed* some experiments on the amount of evaporation from an oak tree, made during the whole period of its summer growth. He found the amount gradually to increase from May to July, and then decrease till October. The number of leaves on the tree he estimates at 751,592 , and the total amount of evaporation in the year at $539^{\circ} 16$ centimetres of water. The average depth of rainfall for the same period on the area covered by the oak tree would be only 65 centimetres; the amount of evaporation is thus 81 times more than that of the rainfall. The excess must be drawn up by the roots from a great depth; and thus trees prevent the gradual drying of a climate, by restoring to the air the moisture which would otherwise be carried to the sea by streams and rivers.

The immediate result, therefore, of the diminution of forests in a thickly-wooded country will be to increase the proportion of the annual rainfall that is carried to the sea by the natural drainage of the country, and proportionately to decrease the amount returned insensibly to the atmosphere, which then condenses into rain and cloud. Within certain limits it is obvious that this must be an unmixed good; but as the country becomes more and more thickly populated, and the land more $\uparrow$ Sitzungsberichte der $k$. bayerischen Akademie der Wissenschaften zu München, $x^{8} 70$, Band $x_{3}$ Heft $x$. 
valuable for habitation or culture, the danger rather lies in the other extreme, that the country will become so denuded of forests as to render the climate too dry for the profitable pursuit of agriculture. This has, in fact, taken place of late years to so great an extent as to demand the most serious attention. In many parts of the continent of Europe great efforts are now being made to restore a portion of the forests which have been ruthlessly destroyed. At one Government establishment in Dalmatia five million young trees are now in cultivation for this purpose. In our Indian possessions the evil resulting from the destruction of the forests reached some years ago so gigantic a dimension as to demand the instant interference of the Government. The Indian forests are in themselves a source of great revenue, producing the most valuable teak, and multitudes of the more ornamental woods used in cabinet-work. But, independently of this, the most injurious consequences had resulted to the climate from their wanton destruction; the droughts, becoming constantly more frequent and of longer duration, brought terrible famine in their rear; and the swollen water-courses, when the rain did come, caused fearful devastations. The Government at length took the subject up, and in all our Indian Provinces the Conservancy of Forests is now an important branch of the Administration, though much yet remains to be done in consolidating and perfecting the system. In Mauritius similar results have followed similar causes. The fertility of the island has been diminished by the destruction of the forests; and the fever which a few years since decimated Port Louis is attributed to the malaria occasioned by the floods brought down by the torrents swollen far beyond their ordinary dimensions.

The iiterature of Forest Conservancy is, in fact, now enormous. The standard work on the subject, as far as India is concerned, is by Dr. Cleghorn,* the Conservator for the Madras Presidency, which gives a history of what our Government has been doing there. We are constantly receiving, however, from others of our colonial dependencies, official reports of the efforts being made in them for the preservation of the native forests; and it is impossible in this connection to avoid mentioning the name of Ferdinand von Mueller, the accomplished Curator of the Botanic Gardens at Melbourne, whose exertions in the introduction and acclimatisation of Australian forest trees in other climes have been unwearied and of inestim. able value.

In Algeria the same tale is told as in "India. Up to about the year 1865 the wanton destruction of the forests by the Arabs by fire and other means, was enormous ; until at length the French Government took up the subject, ably aided by one or two English and French owners of land in the Colony. The tree found there most efficacious in repairing the waste, is not a native, but one of the family known in Australia as "gum-trees," the Eucalyptus globulus of Tasmania. The great advantage of the planting of this tree is, not only the value of its timber, but its prodigiously rapid growth, said to be fully twenty times greater than that of the oak. It has been introduced also with great success into the South of France, owing to the energy and enterprise of v. Mueller, and is hardy in this

* "The Forests and Gardens of South India." By Hugh Cleghorn, M,D. F.L.S. (London; W. H. Allen and Co., I86r.) country. The foliage is said to secrete a gum-resin, which acts as a most valuable antidote to malaria fever.

In the French department of the Hautes Alpes, an interesting experiment has been tried of a somewhat different character. The same results had there ensued from the same causes. Year by year the mountain villages had been abandoned, and in twenty years a diminution of population to the extent of 11,000 had taken place. An attempt to replace the forests met with the most violent opposition from the peasantry, and they were allowed to substitute "gazonnement" for "reboisement;" that is, the people were compelled to returf the barren and neglected districts. The effect is said to have been most beneficial. The fresh covering of the naked soil has prevented evaporation, and has allowed the rain to sink in instead of running off in destructive torrents; and districts which a few years ago were abandoned to desolation are now gradually acquiring a luxuriant vegetation, and giving food and shelter to the flocks and herds which had long been strangers to them; the streams are becoming clearer and less violent, and the bridges are no longer periodically carried away.

There is probably no department of Science to which human energy and ingenuity could be more profitably turned than the reclaiming of the waste places of the earth.

\section{DANA ON CORALS}

Corals and Coral Islands. By James D. Dana, LL.D. \&c. (Sampson Low and Co., 1872.)

7 HE distinguished naturalist, geologist, and minera1 logist, who is the author of this semi-scientific work, is probably, next to Charles Darwin, the man from whom an expansive book on coral formations would be expected. $\mathrm{He}$ has had immense opportunities for the careful investigation of all the phenomena of coral reefs, and his peculiar mental constitution has assisted him in all his endeavours to teach and to arrange. No geologist has equalled Dana in the arrangement of his work; and his celebrated book on that science is eagerly studied by teachers of all degrees. As a student of details, he may point to his Mineralogy with great pride; yet, with these powers and gifts ready at hand, Dana produces, late in life, this disappointing book. It is full of precious stones in ugly settings, and the gems are intermixed with much that is worthless. To the general public it will be almost a closed book for years and it is hardly worthy of a place in a purely scientific library. A great portion of the book is taken up by descriptions and remarks upon animals which are not corals, and which in no way affect or produce coral reefs or islands, and the old errors respecting coral productions are perversely introduced. All the notices and descriptions of the Actiniæ and Hydroidea might have been omitted, as they only confuse the subject, and surely such statements as refer coral making to (1) Polyps, (2) Hydroids, (3) Bryozoa, (4) Algæ, might have been left buried in the memories of those who have been teaching that the third and fourth named organisms have nothing to do with coral any more than oysters and sunflowers.

Writing about Actiniæ, Dana gives the following without reference :- "As to senses, Actiniæ, or the best of them, are not so low as was once supposed; for, besides the 